\title{
Synthesis and quantitative structure-activity relationship study of substituted imidazophosphor ester based tetrazolo[1,5-b]pyridazines as antinociceptive/anti-inflammatory agents
}

\author{
Wafaa M. Abdou*, Neven A. Ganoub and Eman Sabry
}

\section{Full Research Paper}

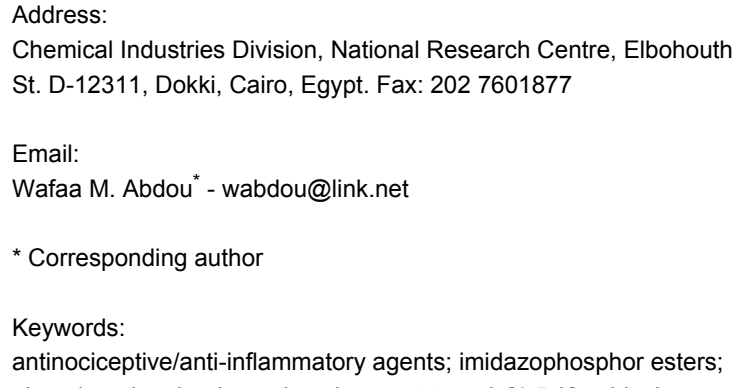

\author{
Beilstein J. Org. Chem. 2013, 9, 1730-1736. \\ doi:10.3762/bjoc.9.199 \\ Received: 01 January 2013 \\ Accepted: 07 June 2013 \\ Published: 22 August 2013 \\ Associate Editor: J. Aubé \\ (c) 2013 Abdou et al; licensee Beilstein-Institut. \\ License and terms: see end of document.
}

\begin{abstract}
A high-yielding general synthesis of imidazophosphor ester based tetrazolo[1,5-b]pyridazines is described. A conjugated reaction between 3,6-diazidopyridazine and different types of phosphonyl carbanion reagents followed by intramolecular cyclization afforded the target products, by using sodium ethanolate solution as a reaction medium. Among the products, five compounds, at a dose of $50 \mathrm{mg}$ per kilogram body weight, showed a notable antinociceptive and anti-inflammatory activity without toxic sideeffects.
\end{abstract}

\section{Introduction}

Inflammation is a characteristic feature of disease pathology and progression in several neuro-degenerative disorders and physical functioning [1,2]. Recently, nonsteroidal anti-inflammatory drugs (NSAIDs) are well established for the treatment of inflammatory disorders [3-5]. The anti-inflammatory effect of NSAIDs is mainly based on the inhibition of the cyclooxygenase (COX) enzymes. Later on, it was reported that the second isoform of cyclooxygenase (COX-2) has a better effect on the inflammation with fewer side-effects [6-9]. Despite their widespread use, none of the presently available agents is ideal; each has its own shortcomings [3]. Subsequently, to improve the effi- cacy/safety profile of new NSAIDs, the structural-activity relationship (SAR) has been extensively studied, taking into account up-to-date knowledge about the mechanism of inflammation that balanced the inhibition of COX-1, COX-2, and lipoxygenase (LOX) [10-12].

As a part of our continued interest in the development of convenient synthetic approaches to $\beta$-enamino- and $\alpha$-aminophosphonates with anti-inflammatory properties [13-20], we recently successfully synthesized a series of mono- and bisphosphonatebased tetrazolo[1,5-a]quinolines with marked anti-inflamma- 
tory properties [21,22]. Following this, synthesis of the target compounds, substituted tetrazolo[1,5-b]pyridazinphosphor esters, is described herein. In this context, we applied different types of phosphonyl carbanion reagents to 3,6-diazidopyridazine (1) as an adopted substrate. The anti-inflammatory and the antinociceptive properties of the prepared compounds were screened and the structure-activity relationships were studied. The anti-inflammatory properties of many tetrazole [21-23] and pyridazine derivatives have also led to their clinical application as NSAIDs (e.g. Bucolome) [24]. Several phosphonate derivatives also exhibit marked potency as inhibitors of COX-1 and COX-2 and are therefore believed to be useful as anti-inflammatory drugs $[25,26]$. Thus, we considered that it is of interest to gather these three motifs in one molecule.

\section{Results and Discussion}

It has been reported that 3,6-diazidopyridazine presents azido (1a) $\rightleftharpoons$ tetrazolo tautomerism (1b) whereby it is mainly in the tetrazole form 1b [27-29]. Accordingly, and as indicated from the spectral data of our products, we considered that the substrate 3,6-diazidopyridazine (1a) is exclusively, throughout our investigation, reacted in the tetrazolo-form $\mathbf{1 b}[28,29]$ (Scheme 1). The required [3,6-diazidopyridazine (1a) 6-azidotetrazolo[1,5-b]pyridazine (1b)] was prepared by treating the readily available 3,6-dichloropyridazine with sodium azide [30]. The reactions studied and the products obtained are depicted in Schemes 1-7 (see below). Reaction of 1b with 1.3 equivalents of methyl diethyl phosphonoacetate (2a) or the ethyl analogue $\mathbf{2 b}$ in sodium ethanolate solution resulted in the same product assigned as diethyl 8-oxo-7,8-dihy-

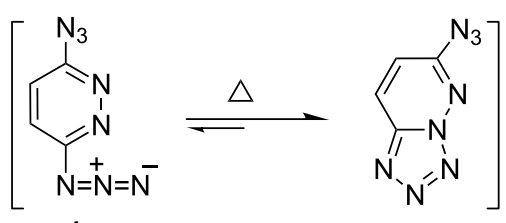

$\mathbf{1 b}+\underset{\substack{\mathrm{O} \\ \mathrm{2a}, \mathbf{2} \mathbf{b}}}{\stackrel{\mathrm{P}(\mathrm{OEt})_{2}}{\stackrel{\text { EtOH/EtONa }}{\longrightarrow}}}$

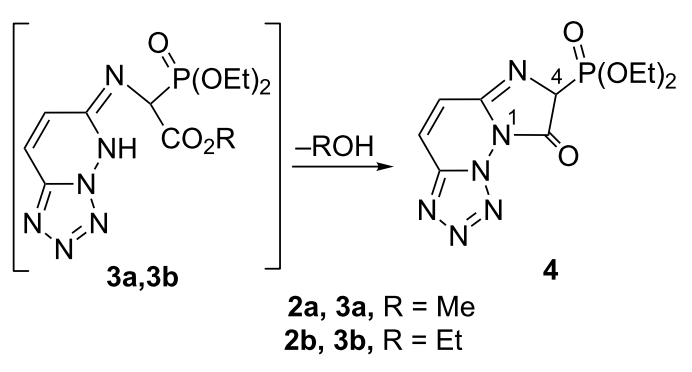

Scheme 1: Synthesis of substituted diethyl oxophosphonate 4. droimidazo[1,2-f]tetrazolo[1,5-b]pyridazin-7-ylphosphonate (4, $78 \%$ ) as indicated from the analytical and the spectroscopic data.

In the ${ }^{1} \mathrm{H}$ NMR spectrum $\left(\mathrm{CDCl}_{3}\right)$ of $\mathbf{4}\left(\delta_{\mathrm{P}}=28.4 \mathrm{ppm}\right)$ there is a doublet peak $\left({ }^{2} J_{\mathrm{P}-\mathrm{H}}=22.3 \mathrm{~Hz}\right)$ at $\delta 5.36 \mathrm{ppm}$ corresponding to $\mathrm{H}(4)$ of the imidazole ring while its $\mathrm{C}(4)-\mathrm{P}$ appeared at $\delta_{\mathrm{C}}=$ $59.4\left(\mathrm{~d},{ }^{1} J_{\mathrm{P}-\mathrm{C}}=148.6 \mathrm{~Hz}\right)$. A plausible mechanism for the formation of tetrazolopyridazinophosphonate 4 is presented in Scheme 1. Upon heating, the equilibrium between the azido-1a and its isomeric tetrazolo-1b form [1a $\rightleftharpoons$ 1b] lies exclusively at the tetrazole isomer $\mathbf{1 b}$ [29]. Compound $\mathbf{1 b}$ is then intercepted by the nucleophilic attack of the phosphonyl carbanion $\mathbf{2} \mathbf{a}$ or $\mathbf{2} \mathbf{b}$ on the azido-function in $\mathbf{1 b}$ yielding the phosphonate intermediate $\mathbf{3}$ along with the evolution of a nitrogen molecule. Subsequent intramolecular ring closure, the fused imidazolo-phosphonate 4 would be obtained under elimination of an appropriate alcohol moiety.

In the same fashion, the substrate $\mathbf{1 b}$ reacted with the phosphonyl carbanion, diethyl cyanomethylphosphonate $\mathbf{5}$, in ethanolate solution to yield diethyl 8-aminoimidazo[1,2-f]tetrazolo[1,5-b]pyridazin-7-ylphosphonate (7) in 74\% yield. The IR spectrum of the phosphonate $7\left(\delta_{\mathrm{P}}=27.8 \mathrm{ppm}\right)$ showed the $\mathrm{NH}_{2}, \mathrm{P}=\mathrm{O}$, and $\mathrm{P}-\mathrm{O}-\mathrm{C}$ motifs at $v$ 3377-3330, 1226, and 1123 $\mathrm{cm}^{-1}$, respectively. Its ${ }^{1} \mathrm{H} \mathrm{NMR}\left(\mathrm{CDCl}_{3}\right)$ spectrum showed the $\mathrm{NH}_{2}$-protons at $\delta 6.44\left(\mathrm{H}^{\mathrm{A}}\right.$, br) and $8.88 \mathrm{ppm}\left(\mathrm{H}^{\mathrm{B}}, \mathrm{br}\right)$, which are attributed to the $\mathrm{P}=\mathrm{O}$ bonding with one proton of the aminogroup. Furthermore, the ${ }^{13} \mathrm{C}$ NMR spectrum of 7 revealed, among others, three doublets at: $\delta 153.6\left[\mathrm{~d},{ }^{3} J_{\mathrm{P}-\mathrm{C}}=11.4 \mathrm{~Hz}\right.$, $\mathrm{C}(2)], 141.2\left(\mathrm{~d},{ }^{1} J_{\mathrm{P}-\mathrm{C}}=188.4 \mathrm{~Hz}, \mathrm{C}(4)-\mathrm{P}\right)$, and at $\delta 126.4$ (d, $\left.{ }^{2} J_{\mathrm{P}-\mathrm{C}}=14.6 \mathrm{~Hz}, \mathrm{C}(5)-\mathrm{NH}_{2}\right) \mathrm{ppm}$. As displayed in Scheme 2, the formation of the fused imidazophosphonate 7 was formed via the initial condensation intermediate 6. Further alkaline hydrolysis of the cyano group and the intramolecular cyclization led to the product 7 (Scheme 2).

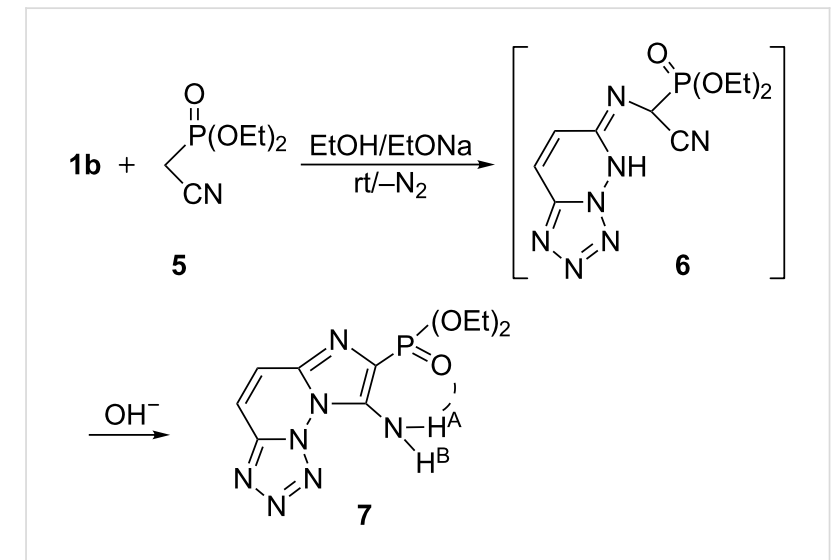

Scheme 2: Synthesis of substituted diethyl aminophosphonate 7. 
Conversely, similar treatment of $\mathbf{1 b}$ with diethyl (methylthioalkyl)phosphonates $\mathbf{8 a}$ and $\mathbf{8 b}$ under the same reaction conditions yielded the fused diazaphospholo-substituted compounds 10a and 10b in 72 and $74 \%$ yield, respectively. The ${ }^{31} \mathrm{P}$ NMR spectrum $\left(\mathrm{CDCl}_{3}\right)$ of the diazaphospholes 10a and10b showed a sharp singlet around $14.5 \mathrm{ppm}$, which is within the range expected for the assigned structure [31].

A mechanism for the formation of the heterophosphole structure $\mathbf{1 0}$ can be rationalized as in Scheme 3 through the condensation of $\mathbf{1 b}$ with $\mathbf{8 a}$ or $\mathbf{8 b}$ to elaborate the intermediates $9 \mathbf{a}$ or $9 \mathbf{b}$ accompanied by the elimination of a $\mathrm{N}_{2}$ molecule. Further intramolecular cyclization of $\mathbf{9}$ afforded the diazaphospholes 10a and 10b, respectively, through the loss of an ethanol molecule [31] (Scheme 3).

$$
\mathbf{1 b}+\sum_{\mathbf{8 a}, \mathbf{8 b}}^{\stackrel{\mathrm{P}(\mathrm{OEt})_{2}}{\mathrm{SR}^{1}} \frac{\mathrm{EtOH} / \mathrm{EtONa}}{\Delta /-\mathrm{N}_{2}}}
$$

$$
\begin{array}{ll}
\mathbf{8 a}-10 a, R^{1}=\mathrm{Me} \\
\end{array}
$$

Scheme 3: Synthesis of fused diazaphospholo-substituted compounds $10 \mathrm{a}, 10 \mathrm{~b}$.

Next, the fused imidazophosphono-substituted compound $\mathbf{1 3}$ (68\% yield) was obtained from the reaction of $\mathbf{1 b}$ with diethyl (2-amino-2-thioxoethyl)phosphonate (11) in ethanolate solution. Obviously, 13 resulted in the same manner from the intermediate 12 initially formed, as outlined in Scheme 4.

Further, the azidotetrazole $\mathbf{1 b}$ was allowed to react with the Horner-Emmons (HE) reactant, tetraethyl methylenebis(phosphonate) (14) under the same reaction conditions to give the respective $\beta$-enaminobisphosphonate 15 ( $\approx 73 \%$ yield). The gem-diphosphonate structure $\mathbf{1 5}$ was delineated from IR, NMR and MS spectra. The IR absorptions for 15 showed the $2 \mathrm{P}=\mathrm{O}$ stretching frequencies as two bands at $1262(\mathrm{P}=\mathrm{O}$, free) and $1226(\mathrm{P}=\mathrm{O}$, bonded $) \mathrm{cm}^{-1}$, which could be explained by a preferred conformation of intramolecular hydrogen bonding between the $\mathrm{NH}$ proton and one of the $\mathrm{P}=\mathrm{O}$ moieties. The ${ }^{31} \mathrm{P}$ NMR spectrum $\left(\mathrm{CDCl}_{3}\right)$ of $\mathbf{1 5}$ showed the presence of two separate doublets with equal ${ }^{2} J_{\mathrm{P}-\mathrm{P}}$ coupling constants $28.4 \mathrm{~Hz}$ at $\delta 25.6$ and $24.8 \mathrm{ppm}$. The ${ }^{1} \mathrm{H}$ and ${ }^{13} \mathrm{C}$ NMR data were also in

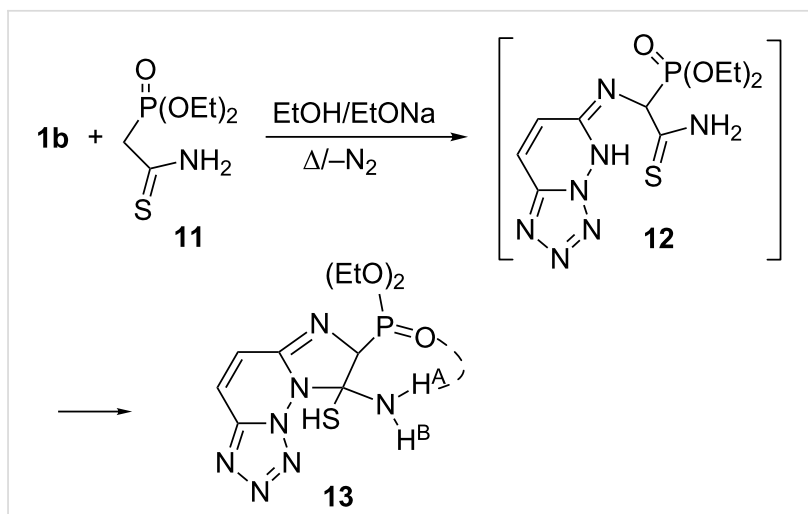

Scheme 4: Synthesis of fused imidazophosphono-substituted compound 13.

accordance with the assigned structure (see Supporting Information File 1). The formation of $\mathbf{1 5}$ can be rationalized as occurring in Scheme 5 through the addition of $\mathbf{1 4}$ to the azido group with concomitant evolution of a molecule of $\mathrm{N}_{2}$ (Scheme 5). Bisphosphonates belong to an important class of BP-drugs used for the treatment of bone diseases such as osteoporosis, hypocalcemia, inflammation and rheumatoid arthritis $[32,33]$.

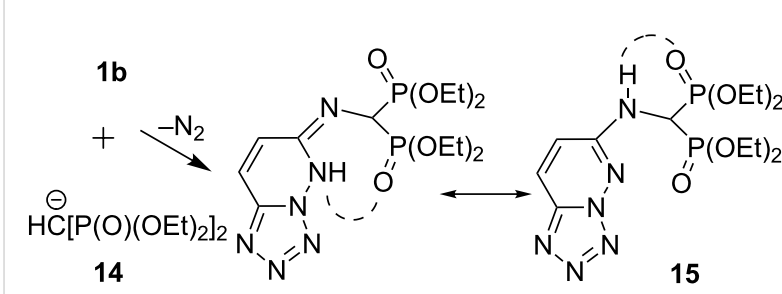

Scheme 5: Synthesis of $\beta$-enaminobisphosphonate 15.

Finally, we studied the behavior of the azidotetrazole $\mathbf{1 b}$ toward the unsaturated HE reactant, diethyl vinylphosphonate (16), and diethyl 2-methylallylphosphonate (18) in EtONa solution to give the fused imidazophosphono-substituted compounds 17 (76\%) and 19 (74\%). Obviously, according to Scheme 6, the coupling cyclization reaction of $\mathbf{1 b}$ with $\mathbf{1 6}$ and auto-oxidation resulted in formation of the final product $\mathbf{1 7}$ in one step. This behavior is familiar in similar reactions. On the other hand, we presume that the allyl reagent $\mathbf{1 8}$, which could be present in the isomeric forms 18a $\rightleftharpoons 18 b$ (Scheme 7), had been conjugated in $\mathbf{1 8 b}$ form with $\mathbf{1 b}$ to give the phosphonate $\mathbf{1 9}$.

In summary, it has been found that the substrate 3,6-diazidopyridazine reacts with nucleophilic phosphorus reagents, HE reactants, mainly in the tetrazole-form leading to the formation of tetrazolopyridazino-imidazophosphor esters or $\beta$-enaminophosphor esters. 


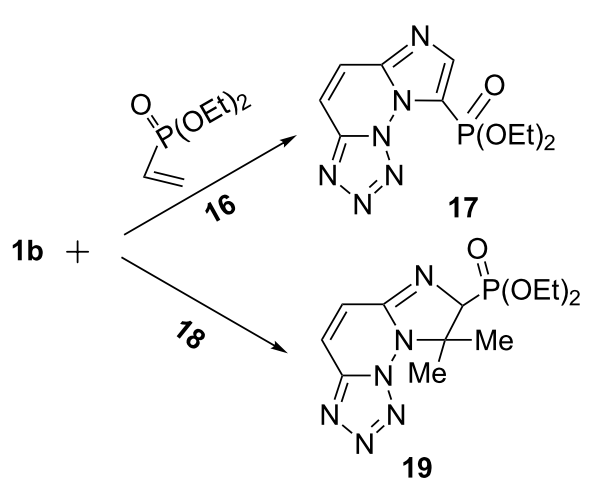

Scheme 6: Synthesis of fused imidazophosphono-substituted compounds 17 and 19.

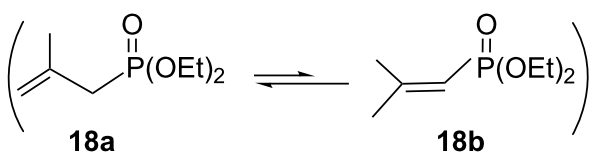

Scheme 7: Isomeric forms of diethyl 2-methylallylphosphonate (18).

\section{Biological assays}

Based on previous reports [24-26] that recognized the pyridazine nucleus is being suitable for anti-inflammatory and antinociceptive agents, and by the fact that ring-fused heterocycles containing more than one nitrogen atom (e.g., tetrazole nuclei [21-23]) are key structures in a large variety of biochemical processes, bioscreening of the synthesized substituted tetrazolo[1,5-b]pyridazine-phosphor derivatives was carried out. Thus, keeping the tetrazolopyridazine core structure intact, we studied the effect of different phosphorus-containing moieties on their antinociceptive and anti-inflammatory effects. Substrate 1 was also tested to reflect the effect of its transformations to our products.

\section{Antinociceptive evaluation para-Benzo- quinone $(p-B Q)$-induced writhing test}

The evaluation of antinociceptive activity of the synthesized compounds was assessed in vivo in mice by using the $p$-benzoquinone-induced writhing test [26]. Ibuprofen was used as a positive control in our experiments; the antinociceptive capacity was expressed as the percentage change compared to writhing controls. The results shown in Table 1 indicated that $\beta$-enam-

\begin{tabular}{|c|c|c|c|c|c|c|}
\hline \multirow[t]{2}{*}{$\begin{array}{l}\text { tested } \\
\text { compound }\end{array}$} & \multirow[t]{2}{*}{$\begin{array}{l}\text { no. of writhings } \pm \text { SEM } \\
\text { (antinociceptive effect, } \%^{b} \text { ) }\end{array}$} & \multicolumn{4}{|c|}{$\begin{array}{l}\text { Swelling in thickness }\left(\times 10^{-2} \mathrm{~mm}\right) \pm \text { SEM } \\
\text { (inhibition of edema, \% })^{c}\end{array}$} & \multirow[t]{2}{*}{$\begin{array}{l}\text { anti-inflammatory activity } \\
\text { after } 360 \mathrm{~min}, \%\end{array}$} \\
\hline & & $90 \min$ & $180 \mathrm{~min}$ & $270 \mathrm{~min}$ & $360 \mathrm{~min}$ & \\
\hline control & $28.6 \pm 2.4$ & $41.4 \pm 3.3$ & $55.2 \pm 2.7$ & $74.8 \pm 3.6$ & $78.2 \pm 4.1$ & - \\
\hline $4^{d}$ & $\begin{array}{l}6.8 \pm 2.2 \\
(76.2)^{*}\end{array}$ & $\begin{array}{l}30.2 \pm 3.8 \\
(27.1)^{*}\end{array}$ & $\begin{array}{l}28.9 \pm 4.6 \\
(47.6)^{\star \star}\end{array}$ & $\begin{array}{l}37.4 \pm 5.7 \\
(50.0)^{* *}\end{array}$ & $\begin{array}{l}31.3 \pm 5.6 \\
(60)^{\star \star *}\end{array}$ & $(96.8)^{\star \star}$ \\
\hline $7^{d}$ & $\begin{array}{l}5.4 \pm 4.3 \\
(81.1)^{* *}\end{array}$ & $\begin{array}{l}31.8 \pm 5.3 \\
(23.2)^{\star}\end{array}$ & $\begin{array}{l}25.1 \pm 5.6 \\
(54.5)^{\star}\end{array}$ & $\begin{array}{l}33.8 \pm 3.4 \\
(54.8)^{\star * \star}\end{array}$ & $\begin{array}{l}27.4 \pm 6.4 \\
(65.0)^{*}\end{array}$ & 104.8 \\
\hline $10 a^{d}$ & $\begin{array}{l}5.8 \pm 2.9 \\
(79.7)^{\star * *}\end{array}$ & $\begin{array}{l}30.6 \pm 6.3 \\
(26.1)^{\star *}\end{array}$ & $\begin{array}{l}26.3 \pm 5.6 \\
(52.4)^{* *}\end{array}$ & $\begin{array}{l}34.6 \pm 3.6 \\
(53.7)^{* * *}\end{array}$ & $\begin{array}{l}27.9 \pm 4.3 \\
(64.3)^{* * *}\end{array}$ & 103.7 \\
\hline $10 b^{d}$ & $\begin{array}{l}6.3 \pm 2.9 \\
(77.9)^{*}\end{array}$ & $\begin{array}{l}30.8 \pm 3.8 \\
(25.6)^{*}\end{array}$ & $\begin{array}{l}27.1 \pm 4.7 \\
(50.9)^{*}\end{array}$ & $\begin{array}{l}35.6 \pm 6.0 \\
(52.4)^{\star \star \star}\end{array}$ & $\begin{array}{l}28.8 \pm 4.8 \\
(63.2)^{\star \star \star}\end{array}$ & 102 \\
\hline $13^{d}$ & $\begin{array}{l}4.4 \pm 2.2 \\
(84.6)^{*}\end{array}$ & $\begin{array}{l}30.7 \pm 3.3 \\
(25.8)^{\star *}\end{array}$ & $\begin{array}{l}23.4 \pm 5.6 \\
(57.6)^{* *}\end{array}$ & $\begin{array}{l}33.2 \pm 3.6 \\
(55.6)^{\star * *}\end{array}$ & $\begin{array}{l}25.8 \pm 4.3 \\
(67.0)^{\star * \star}\end{array}$ & 108 \\
\hline $15^{\mathrm{d}}$ & $\begin{array}{l}3.9 \pm 2.1 \\
(86.4)^{\star *}\end{array}$ & $\begin{array}{l}28.9 \pm 5.2 \\
(30.2)^{\star * \star}\end{array}$ & $\begin{array}{l}21.6 \pm 7.4 \\
(60.9)^{\star \star \star}\end{array}$ & $\begin{array}{l}28.2 \pm 5.0 \\
(62.3)^{* * *}\end{array}$ & $\begin{array}{l}22.8 \pm 6.7 \\
(70.8)^{\star * *}\end{array}$ & 114 \\
\hline $17^{d}$ & $\begin{array}{l}7.6 \pm 1.7 \\
(73.4)^{\star * *}\end{array}$ & $\begin{array}{l}30.4 \pm 7.2 \\
(26.5)^{\star * *}\end{array}$ & $\begin{array}{l}29.3 \pm 4.1 \\
(46.9)^{\star *}\end{array}$ & $\begin{array}{l}39.1 \pm 4.2 \\
(47.7)^{\star * *}\end{array}$ & $\begin{array}{l}30.7 \pm 4.5 \\
(60.7)^{\star * *}\end{array}$ & 97.9 \\
\hline $19^{d}$ & $\begin{array}{l}7.2 \pm 2.1 \\
(74.8)^{* * \star}\end{array}$ & $\begin{array}{l}29.7 \pm 4.6 \\
(28.0)^{*}\end{array}$ & $\begin{array}{l}28.7 \pm 5.6 \\
(48.0)^{\star *}\end{array}$ & $\begin{array}{l}38.5 \pm 5.2 \\
(48.6)^{\star * \star}\end{array}$ & $\begin{array}{l}31.9 \pm 3.8 \\
(59.2)^{\star * \star}\end{array}$ & 95.5 \\
\hline 1 & $\begin{array}{l}24.6 \pm 2.3 \\
(14.0)^{\star \star}\end{array}$ & $\begin{array}{l}36.8 \pm 6.9 \\
(11.1)^{\star \star}\end{array}$ & $\begin{array}{l}44.6 \pm 5.4 \\
(19.2)^{\star \star}\end{array}$ & $\begin{array}{l}56.8 \pm 5.5 \\
(24.0)^{\star *}\end{array}$ & $\begin{array}{l}62.4 \pm 3.8 \\
(20.2)^{\star \star \star}\end{array}$ & 32.6 \\
\hline ibuprofen & $\begin{array}{l}8.7 \pm 3.1 \\
(69.6)^{* * *}\end{array}$ & & & & & \\
\hline indomethacin & & $\begin{array}{l}34.6 \pm 4.6 \\
(16.4)^{* *}\end{array}$ & $\begin{array}{l}32.4 \pm 4.4 \\
(41.3)^{*}\end{array}$ & $\begin{array}{l}31.4 \pm 1.6 \\
(58.02)^{* * *}\end{array}$ & $\begin{array}{l}29.8 \pm 3.4 \\
(62.0)^{* * *}\end{array}$ & 100 \\
\hline
\end{tabular}

aData obtained from animal experiments are expressed as means \pm SEM (dose $=50 \mathrm{mg}$ per kilogram body weight, administered subcutaneously to mice $(n=6-8)$. ${ }^{b} p-B Q$-induced writhing; ${ }^{c} C G$-induced paw edema tests, respectively. ${ }^{d}$ Statistical significance was evaluated from the control by oneway ANOVA post hoc Dunnett's test $\left({ }^{*} p<0.05,{ }^{* *} p<0.01\right.$, $\left.{ }^{* \star *} p<0.001\right)$. 
inobisphosphonate $\mathbf{1 5}$ is the most potent antinociceptive structure $(86.4 \%)$, which was followed by $\alpha$-aminophosphonates $\mathbf{1 3}$ (84\%) and 7 (81\%). Indeed, while the azido substrate 1 showed only a weak antinociceptive effect (14\%), the eight phosphor compounds demonstrated higher capacity than the reference ibuprofen drug (69.9\%) at the same dose of $50 \mathrm{mg}$ per kilogram body weight.

\section{Anti-inflammatory screening Carrageenan-induced hind paw edema test}

Anti-inflammation properties of the new tetrazolo[1,5-b]pyridazines-bearing mono- $(4,7,10 a, 10 b, 13,17,19)$ and diphosphonate nuclei (15) were evaluated in an animal model, by the carrageenan-induced paw edema (CPE) method. Following the standard procedures $[34,35]$, these compounds were administered subcutaneously by using $50 \mathrm{mg}$ per kilogram body weight, and the anti-inflammatory effect was measured at successive time intervals $(90,180,270$, and $360 \mathrm{~min}$, after carrageenan injection). The results are profiled in Table 1 and are compared to the substrate $\mathbf{1}$ and to indomethacin (A). $\beta$-Enaminobisphosphonate $\mathbf{1 5}$ showed the most potent inflammatory properties (e.g., $114 \%$ after $360 \mathrm{~min}$ ) relative to indomethacin. Nevertheless, other compounds displayed good to excellent effects (95 to
$108 \%$ ) in inflammation inhibition after 360 min comparing to $\mathbf{A}$ without toxic effects. Percentage inhibition of granuloma for the tested compounds at a dose of $50 \mathrm{mg}$ per kilogram body weight at successive intervals is displayed in Figure 1.

According to the results of the biological assay in Table 1, we could deduce the structure-activity relationship (SAR) as follows: (1) among the tested compounds, $\beta$-enaminobisphosphonate $\mathbf{1 5}$ has the most antinociceptive/anti-inflammatory activity, even higher than the references ibuprofen and indomethacin; (2) there is a parallel correlation between the anti-inflammatory activities and the antinociceptive activity results (Table 1); (3) the amino group substituent has a positive effect (see 7 and 13); (4) like indomethacin, the tested phosphonates showed gradual increase in the second phase (after 270 $\min )$.

\section{$\mathrm{LD}_{50}$ of the most promising products}

In an acute-toxicity experiment, the most promising anti-inflammatory compounds $\mathbf{1 5}, 7$, and $\mathbf{1 3}$ were tested using the $\mathrm{LD}_{50}$ standard method in mice at doses of 500, 750 and $1000 \mathrm{mg}$ per kilogram body weight, which is $10-20$ times the used antiinflammatory effective dose (50 mg per kilogram body weight).

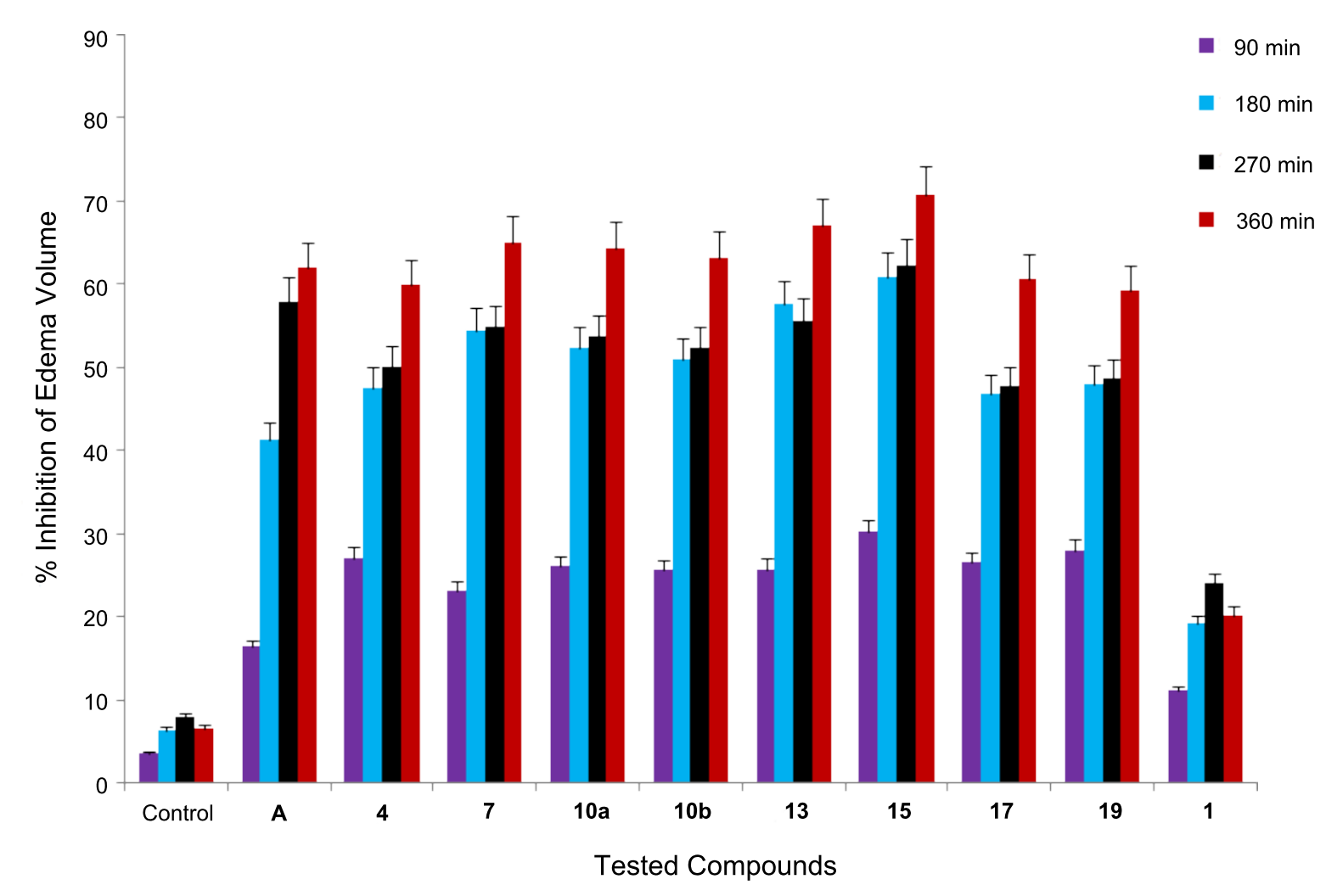

Figure 1: Percentage inhibition of granuloma for the tested compounds at a dose of $50 \mathrm{mg}$ per kilogram body weight after the given time intervals. Error bar: $5 \%$. 
The assay did not show toxic symptoms or mortality rates throughout the following $24 \mathrm{~h}$ post-administration, indicating the safety of the used doses.

\section{Conclusion}

In summary, we have offered a practical and efficient procedure for the synthesis of imidazophosphor esters based tetrazolo[1,5-b]pyridazine in high yields by application of different types of Horner-Emmons (HE) reagents on 3,6-diazidopyridazine. Among the products, the $\beta$-enaminobisphosphonate compound demonstrated the highest antinociceptive and the anti-inflammatory activities.

\section{Experimental}

See Supporting Information File 1 for full experimental data

\section{Supporting Information}

The experimental section, the general procedures, the experimental data, the results of the analyses, and the bioassay procedures are included in Supporting Information File 1.

\section{Supporting Information File 1}

Full experimental details.

[http://www.beilstein-journals.org/bjoc/content/ supplementary/1860-5397-9-199-S1.pdf]

\section{Acknowledgements}

The authors would like to thank the Central Lab, School of Pharmacy, Alexandria University, Egypt.

\section{References}

1. Hamor, G. H. Non-steroidal anti-inflammatory drugs. In Principles of Medicinal Chemistry, 3rd ed.; Foye, W. O., Ed.; LEA \& Febiger: Philadelphia, London, 1989; pp 503-530.

2. Harrak, K.; Rossel, G.; Daidone, G.; Plescia, S.; Schillaci, D.; Pujol, M. D. Bioorg. Med. Chem. 2007, 15, 4876-4890. doi:10.1016/j.bmc.2007.04.050

3. Inagaki, M.; Tsuri, T.; Jyoyama, H.; Ono, T.; Yamada, K.; Kobayashi, M.; Hori, Y.; Arimura, A.; Yasui, K.; Ohno, K.; Kakudo, S.; Koizumi, K.; Suzuki, R.; Kato, M.; Kawai, S.; Matsumoto, S. J. Med. Chem. 2000, 43, 2040-2048. doi:10.1021/jm9906015

4. Flower, R. J. Nat. Rev. Drug Discovery 2003, 2, 179-191. doi:10.1038/nrd1034

5. Dannhardt, G.; Kiefer, W. Eur. J. Med. Chem. 2001, 36, 109-126. doi:10.1016/S0223-5234(01)01197-7

6. Penrose, J. F.; Austen, K. F.; Lam, B. K. Leukotrienes: Biosynthetic Pathways, Release and Receptor-Mediated Actions with Relevance to Disease States. In Inflammation Basic Principles and Clinical Correlates; Gallin, J. L.; Snyderman, R., Eds.; Lippicort Williams \& Wilkins: Philadelphia, 1999; pp 361-372.
7. Vane, J. R.; Bakhle, Y. S.; Botting, R. M. Annu. Rev. Pharmacol. Toxicol. 1998, 38, 97-120. doi:10.1146/annurev.pharmtox.38.1.97

8. Dirig, D. M.; Isakson, P. C.; Yaksh, T. L. J. Pharmacol. Exp. Ther. 1998, 285, 1031-1038.

9. Martel-Pelletier, J.; Lajeunesse, D.; Reboul, P.; Pelletier, J.-P. Ann. Rheum. Dis. 2003, 62, 501-509. doi:10.1136/ard.62.6.501

10. Pontiki, E.; Hadjipavlou-Litina, D.; Litinas, K.; Nicolotti, O.; Carotti, A. Eur. J. Med. Chem. 2011, 46, 191-200. doi:10.1016/j.ejmech.2010.10.035

11. Roussaki, M.; Kontogiorgis, C. A.; Hadjipavlou-Litina, D.; Hamilakis, S.; Detsi, A. Bioorg. Med. Chem. Lett. 2010, 20, 3889-3892. doi:10.1016/j.bmcl.2010.05.022

12. Rajić, Z.; Hadjipavlou-Litina, D.; Pontiki, E.; Kralj, M.; Šuman, L.; Zorc, B. Chem. Biol. Drug Des. 2010, 75, 641-652. doi:10.1111/j.1747-0285.2010.00963.x

13. Abdou, W. M.; Barghash, R. F.; Bekheit, M. S. Arch. Pharm. 2012, 345, 884-895. doi:10.1002/ardp.201200142

14. Abdou, W. M.; Barghash, R. F.; Bekheit, M. S. Monatsh. Chem. 2011, 142, 649-656. doi:10.1007/s00706-011-0492-8

15. Abdou, W. M.; Khidre, R. E.; Barghash, R. F. Synth. Commun. 2012, 42, 1967-1978. doi:10.1080/00397911.2010.551170

16. Abdou, W. M.; Barghash, R. F.; Bekheit, M. S. RSC Adv. 2013, 3, 1528-1540. doi:10.1039/c2ra22769j

17. Sediek, A. A.; Shaddy, A. A.; Abdou, W. M. J. Heterocycl. Chem. 2011, 48, 1258-1263. doi:10.1002/jhet.743

18. Abdou, W. M.; Khidre, M. D.; Khidre, R. E. Eur. J. Med. Chem. 2009, 44, 526-532. doi:10.1016/j.ejmech.2008.03.032

19. Abdou, W. M.; Shaddy, A. A.; Sediek, A. A. J. Chem. Res. 2009, 8-13. doi:10.3184/030823409X393646

20. Abdou, W. M.; Sediek, A. A.; Khidre, M. D. Monatsh. Chem. 2008, 139 , 617-623. doi:10.1007/s00706-007-0806-z

21. Abdou, W. M.; Khidre, R. E.; Shaddy, A. A. J. Heterocycl. Chem. 2013, 50, 33-41. doi:10.1002/jhet.968

22. Abdou, W. M.; Khidre, R. E.; Kamel, A. A. Arch. Pharm. 2012, 345, 123-136. doi:10.1002/ardp.201100080

23. Bhaskar, V. H.; Mohite, P. B. J. Optoelectron. Biomed. Mater. 2011, 3, 7-16.

24. Tewari, A. K.; Mishra, A. Bioorg. Med. Chem. 2001, 9, 715-718. doi:10.1016/S0968-0896(00)00285-6

25. Salari, H.; Bittman, R. Phosphonates as anti-inflammation agents. U.S. Patent US5219845, June 15, 1993.

26. Al Quntar, A. A. A.; Gallily, R.; Katzavian, G.; Srebnik, M. Eur. J. Pharmacol. 2007, 556, 9-13. doi:10.1016/j.ejphar.2006.10.041

27. Deep, A.; Sterk, H.; Kappe, T. Liebigs Ann. Chem. 1991, 1225-1227. doi:10.1002/jlac.1991199101210

28. Tisler, M. Synthesis 1973, 123-136. doi:10.1055/s-1973-22145

29. Kategaonkar, A. H.; Sapkal, S. B.; Madje, B. R.; Shingate, B. B.; Shingare, M. S. Chem. Heterocycl. Compd. 2010, 46, 754-758. doi:10.1007/s10593-010-0579-x

30. Shin, M.-S.; Kang, Y.-J.; Chung, H.-A.; Park, J.-W.; Kweon, D.-H.; Lee, W. S.; Yoon, Y.-J.; Kim, S.-K. J. Heterocycl. Chem. 1999, 36, 1135-1142. doi:10.1002/jhet.5570360504

31. He, L.-N.; Cai, F.; Chen, R.-Y.; Zhou, J. Phosphorus, Sulfur Silicon Relat. Elem. 1997, 130, 65-71. doi:10.1080/10426509708033698

32. Ghosh, S.; Chan, J. M. W.; Lea, C. R.; Meints, G. A.; Lewis, J. C.; Tovian, Z. S.; Flessner, R. M.; Loftus, T. C.; Bruchhaus, I.; Kendrick, H.; Croft, S. L.; Kemp, R. G.; Kobayashi, S.; Nozaki, T.; Oldfield, E. J. Med. Chem. 2004, 47, 175-187. doi:10.1021/jm030084x 
33. Russell, R. G. G. Ann. N. Y. Acad. Sci. 2006, 1068, 367-401. doi:10.1196/annals.1346.041

34. Okun, R.; Liddon, S. C.; Lasagna, L. J. Pharmacol. Exp. Ther. 1963, 139, 107-109.

35. Winter, C. A.; Risley, E. A.; Nuss, G. W. Proc. Soc. Exp. Biol. Med. 1962, 111, 544-547.

\section{License and Terms}

This is an Open Access article under the terms of the Creative Commons Attribution License

(http://creativecommons.org/licenses/by/2.0), which permits unrestricted use, distribution, and reproduction in any medium, provided the original work is properly cited.

The license is subject to the Beilstein Journal of Organic Chemistry terms and conditions:

(http://www.beilstein-journals.org/bjoc)

The definitive version of this article is the electronic one which can be found at: doi:10.3762/bjoc.9.199 